\title{
"I am a virgin woman and a virgin woman's child« Critical Plant Theory and the Maiden Mother Conceit in Early Medieval Riddles
}

\author{
Alaric Hall and Shamira A. Meghani*
}

While early medieval riddles in Old English and, to a lesser extent, Latin, have been studied extensively from ecocritical perspectives in recent years, the large corpora of riddles in other languages of western Eurasia have yet to benefit from or feed back into these methodological developments. Meanwhile, ecocritical research generally has focused on animals at the expense of plants. We respond to both problems by providing the first extensive study of riddles whose solutions are plants, through the lens of one recurrent conceit in ancient and medieval verse riddles in Arabic, Greek, Latin, Old Norse and, we argue, Hebrew. The conceit is that a plant is a virgin woman who nevertheless reproduces. By examining different permutations of this motif, we show how these riddles use plants to comment on human gendering, and how, while usually fundamentally patriarchal in their world-views, they register patriarchal anxiety at women's reproductive capabilities, acknowledge critiques of patriarchal constraints on women, and queer gender norms in other ways; inter alia we note that the Old Norse riddle studied here may be the only explicit (albeit metaphorical) representation of female homosexual eroticism in the Old Norse corpus. However, we also draw on critical plant theory to explore how the riddles situate plants in medieval Abrahamicate cultures, uncovering implicit recognitions of the dynamic and reciprocal relationships between human farmers and their family structures, the plants that domesticate them, people's and plants' mutual shaping of the ecosystems they inhabit or colonise, and the economies that these interactions constitute.

Keywords: riddles, critical plant theory, Abrahamicate, ekphrasis, Dunash ben Labrat ha-Levi, Heiðreks saga, ecocriticism, sexuality

\section{Introduction}

This article examines a single conceit in early medieval riddles from the Mediterranean basin and the northeastern Atlantic seaboard: the idea that a thing might be a mother, yet a virgin. The solution to these riddles is not Mary, the mother of Jesus, but various species of plant. By analysing this conceit, this article looks at early medieval culture from a number of unusual

* Correspondence details: Alaric Hall, corresponding author: a.t.p.hall@leeds.ac.uk; Shamira A. Meghani: sm2258@cam.ac.uk 
angles. Perhaps most importantly, we contribute to critical plant studies, a relatively young movement within the more established field of ecocriticism. Within critical plant studies, as the recent survey of Allor and Swenson emphasises, the Middle Ages are relatively neglected, and the work that is being done focuses on trees. ${ }^{1}$ The texts on which we focus here are about roses, artichokes, palms, angelicas, and grapevines, calling attention to the interactions and interdependencies between medieval culture and other kinds of vegetal life. We also work to move research on medieval riddles beyond Old English and Latin. The last two decades have seen an explosion of insightful, increasingly ecologically orientated research on these riddles. ${ }^{2}$ Yet the substantial early medieval corpora of riddles in other languages have enjoyed far less attention. Showing that the maiden mother conceit was found on both sides of the Indo-European/Semitic language divide in early medieval riddling - and also, we suggest, resolving some doubt as to the correct solutions to a couple of riddles - we identify a small but well-defined corpus of true riddles (that is, riddles whose puzzle depends on metaphor rather than puns or other linguistic play) across Greek, Arabic, Hebrew, and Old Norse. Our linguistic limits have constrained us to these languages, but other examples are certainly found in medieval riddle-like Persian verse, ${ }^{3}$ and the conceit might have a wider distribution again. The demonstrable participation of those riddles that we have studied in a shared literary culture indicates the validity of comparing the same riddles in other ways. We build on work on Old English riddles to start to write a cultural-ecological history reaching beyond the redoubts of Eurocentric medieval studies and the Anglophone focus of much ecocritical literary research. And while there is burgeoning ecotheological research on medieval Christian culture, there is little - at least in English - on Judaism and Islam. This study hints at the possibilities that await a wider-ranging Abrahamic ecotheology.

In Culture and Imperialism, Edward W. Said enjoined his readers to understand territories and regions as overlapping, rather than segmented by borders or into recent national projects, and to understand the knowledge produced in them as a product of exchange. ${ }^{4} \mathrm{We}$ argue that it also serves the notion of ecology and plant studies to think about literary texts as cross-fertilised through shared literary forms. More recently, contemplating the possibilities for studying the "Muslim world system « within global history, Francis Robinson has advocated the investigation of its "shared worlds of knowledge and experience", highlighting the merits of studying "the world of storytelling «, "astrology«, and »commodities of global impact $" .5$ We can readily extend Robinson's ideas to contemplate an "Abrahamic world system « incorporating those parts of the world where Abrahamic religions were culturally dominant, and adapt to this purpose Marshall Hodgson's term Islamicate, which Hodgson used to denote sthe social and cultural complex historically associated with Islam and the Muslims, both among Muslims themselves and even when found among non-Muslims«. Though

1 Allor and Swenson, Writing with plants.

2 Major studies include Niles, Old English Enigmatic Poems; Bitterli, Say What I am Called; Murphy, Unriddling the Exeter Riddles; Price, Human and NonHuman; Dale, Natural World in the Exeter Book Riddles; Paz, Nonhuman Voices in Anglo-Saxon Literature; Sebo, In Enigmate.

3 Seyed-Gohrab, Courtly Riddles, 48-52.

4 Said, Culture and Imperialism, 3-61.

5 Robinson, Global history from an Islamic angle, 136-141. 
named after a religion, the Islamicate complex - unlike Islam per se - was not narrowly defined by religion but also non-religious cultural contiguities. ${ }^{6}$ Some of the riddles that we address here can usefully be read as being Abrahamic - purposefully meditating on Abrahamic religious ideas - but most or all can be read as Abrahamicate. Although Robinson's interest in astrology is not addressed in this article - notwithstanding the fact that heavenly bodies fall firmly within the purview of early medieval riddling across Eurasia - the present article does study Robinson's "world of storytelling". Moreover, our plant riddles also afford food for thought regarding the long-distance transmissions of agricultural crops and practices to which Robinson adverted when advocating the study of global commodities. Just as riddles have the power to defamiliarise and re-enchant the mundane, they allow us to look again at the banal observation that international folkloric motifs travel widely and that Abrahamicate cultures had a lot in common and instead trace historical particularities in the continuities and disjunctions of those cultures.

\section{Mapping the Maiden Mother Conceit}

We begin by establishing our primary sources, and with a riddle whose solution past scholarship has found obscure. It is the last of ten two-line riddles attributed to the seminal medieval Hebrew poet (and husband to probably the only known female Hebrew-language poet of the Middle Ages), Dunash ben Labrat ha-Levi (920×925-after 985)..$^{7}$ Following spells in both the Maghreb and Iraq, Dunash was writing in al-Andalus. ${ }^{8}$ The earliest manuscript of the riddle is the Cairo Geniza fragment Philadelphia, University of Pennsylvania, Center for Advanced Judaic Studies Library, Cairo Genizah Collection, Halper 317, f. 2v (lines 29-30), from between the tenth and twelfth century. ${ }^{9}$

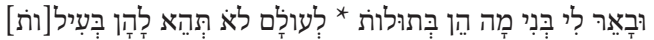

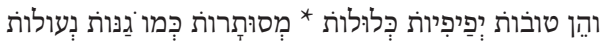

Explain to me, my son, what are the virgins * that never receive a man. They return beautiful, intact, ${ }^{*}$ enclosed with fenced gardens.

7 With the exception of recent authors whose names are conventionally spelled otherwise, we romanise all nonLatin scripts using the American Library Association-Library of Congress ALA-LC Romanization Tables: Transliteration Schemes for Non-Roman Scripts at https://www.loc.gov/catdir/cpso/roman.html.

8 Delgado, Dunash ben Labraț ha-Levi.

9 Dunash ben Labrat ha-Levi, hidot ed. Aluny, 146. Translations are, unless otherwise stated, our own; in this case our translation draws on Dunash ben Labraț ha-Levi, diwan, trans. Rodríguez, 228. Rodríguez's translation reads "Explícame, hijo mío, cuáles son las vírgenes * que jamás reciben varón. | Hermosas tornan, íntegras, * cerradas con jardines cercados". Aluny's edition is impressively cryptic, giving no call numbers for the three manuscripts it cites and only patchy bibliographical information on secondary sources; Rodríguez refrained from trying to unravel these problems, contenting himself with translating Aluny's edition of Halper 317 (which happily is now available in an open-access facsimile: openn.library.upenn.edu/Data/0002/html/h317.html). If our ongoing endeavours to fill in the blanks left by Aluny succeed, we will add the information to en.wikipedia.org/wiki/ Riddles_of_Dunash_ben_Labrat. 
Editing the same riddle as the second of seven which they attributed to the eleventh-century Shelomo ben Yehuda ibn Gabirol (an attribution no longer accepted), Hayim Nahman Bialik and Yehoshua Hana Rawnitzki recorded earlier speculation that the riddle might concern agriculture ${ }^{10}$ Bialik and Rawnitzki did not develop this suggestion, however, while Nehemya Aluny offered "new verses or ideas " as the solution. ${ }^{11}$ But Aluny did not make a substantive case for this, and Rodríguez, in his Spanish translation of Dunash's diwan, wrote simply that "la solución no aparece clara" (»the solution is unclear"). ${ }^{12}$

Some debate also surrounds the solution to a Greek riddle, first attested as verse fortytwo of book fourteen of the Palatine Anthology, the principal manuscript of the so-called Greek Anthology, a massive collection of Greek poetry which came into its present form in the years around 900 and comprises one of our main repositories of ancient and early medieval Greek verse. The Palatine Anthology is a tenth-century manuscript of this collection from Constantinople, preserved now as the disiecta membra Heidelberg, Universitätsbibliothek Heidelberg, Cod. Pal. graec. 23 and Paris, Bibliothèque Nationale, Supplément grec. 384:13

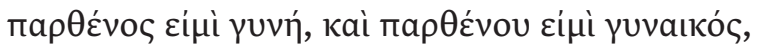

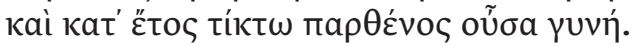

I am a virgin woman and a virgin woman's child, and being a virgin woman I bring forth every year.

Medieval Greek riddles are fond of family metaphors, including fathers begetting children without mothers, ${ }^{14}$ but the formulation here, which parallels Dunash's image of maidens reproducing without men, is distinctive. The antiquity of this riddle is uncertain; Milovanović did not include it in her collection of Byzantine riddles, ${ }^{15}$ perhaps because its elegiac form suggests pre-Byzantine composition..$^{16}$ The Palatine Anthology records no solution to the riddle, but the margin of Florence, Biblioteca Medicea Laurenziana, Plutei 32.16, f. 382v, an independent witness to the Greek Anthology, copied by the Byzantine monk Maximus Planudes in the last two decades of the thirteenth century, gives the solution, in what looks

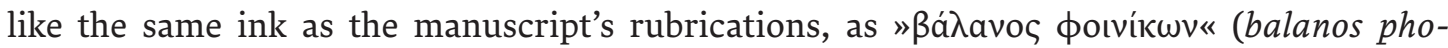
inikōn, literally "acorn of the Phoenicians", meaning "fruit of the date-palm «). ${ }^{17}$ The manuscript does not record a solution for every riddle and it is not certain why Maximus included this one - was he confident as to the answer to this riddle, but not sure of some of the others? Or, conversely, did he find this riddle obscure, thinking that his readers would be grateful if he offered his own guess? Either way, W. R. Paton endorsed the date solution in his Loeb translation, with the observation that date palms are unique in that the trees are either male

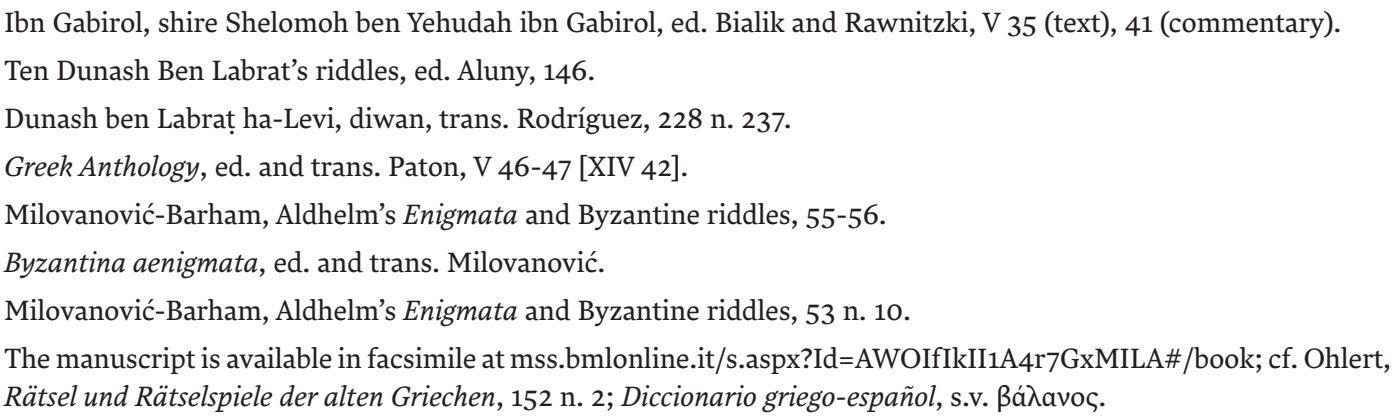


(pollen-producing) or female (flower- and fruit-producing): since, in the wild, the pollen is carried by the wind rather than insects, the female trees might be thought ostensibly to reproduce self-sufficiently. However, Konrad Ohlert, in the first edition of his major study of Greek riddling, was for some reason dissatisfied with the evidence of Plutei 32.16 and suggested "grapevine" on the grounds that this is the solution to Symphosius's riddle 53, which also uses the maiden mother conceit (and is discussed below).$^{18}$ Meanwhile, Félix Buffière disliked both solutions and proposed that this riddle shares its solution with the two that precede it in the Palatine Anthology, which are agreed to be on »day and night «. ${ }^{19}$

What at least some of these commentators appear not to have known is that the conceit of the maiden who reproduces is well attested in early medieval riddles; moreover, the solutions to these riddles are recorded in the manuscripts, and are usually plants. In this conceit, the fact that virgins are people indicates that the solution to the riddle will not be a person; the fact that the virgins reproduce hints that the subject will be a life form; and the fact that the reproduction does not ostensibly involve sexual intercourse indicates that the life form will be a plant. Admittedly the conceit is not always used in this way: the Bern Riddles (on which more below) also use it of an egg. ${ }^{20}$ But its deployment for plants is widespread. The earliest example of which we are aware occurs as the fifty-third of the hundred Latin riddles of Symphosius, thought to have been composed in the late fourth or early fifth century, possibly - but far from certainly - in North Africa. ${ }^{21}$

nolo toro iungi, quamvis placet esse maritam.

nolo virum thalamo: per me mea nata propago est.

nolo sepulchra pati; scio me submergere terrae

I do not want to be joined in marriage, although being married is pleasing.

I do not want a husband for my bedchamber: my offspring is born through me.

I do not want to encounter tombs: I know how to bury myself in the earth.

Like Greek riddlers, Symphosius made extensive use of family metaphors, ${ }^{22}$ but the maiden mother conceit here is distinctive in his oeuvre. The conceit recurs in the riddle »de rosa" (»on the rose") in the so-called Bern Riddles, no doubt composed under the direct textual influence of Symphosius, probably in the Mediterranean region (and perhaps specifically northern Italy) around the seventh century. ${ }^{23}$ In the critical edition of Glorie, the riddle runs: ${ }^{24}$

Mollis ego duro de corde genero natos;

In conceptu numquam amplexu uiri delector.

Sed dum infra meis concrescunt fili latebris,

Meum quisque nascens disrumpit uulnere corpus.

Postquam decorato uelantes tegmine matrem

Saepe delicati frangunt acumine fortes. an African?

22 Mogford, Moon and stars, 231-32.

23 Klein, Latin Bern Riddles; Mogford, Moon and stars, 231.

24 Aenigmata in Dei nomine Tullii, ed. Glorie, 599 (no. 52). 
Soft as I am, I produce sons from my hard heart;

in conceiving I am never delighted by the embrace of a man.

But as my sons grow strong beneath my hiding places,

each ruptures my body with a wound as it is born.

Thereafter, covering their mother with an ornate blanket,

the weak often break the strong with a sharp point.

Most of the riddles studied in this article are attested in just one, two, or three primary manuscripts, with little significant textual variation (while Symphosius's are found in over thirty, but with a well-established critical text). Being sure of the best text of this Bern riddle is trickier; there are at least five witnesses to Riddle 52, yet editors have had to introduce conjectural readings to create a legible critical text. ${ }^{25}$ As Neville Mogford has recently discussed, the metaphors of the Bern Riddles sometimes become convoluted, ${ }^{26}$ making it harder for medieval scribes and modern editors alike to infer the best reading. But for the purposes of our argument, the text and meaning of the riddle is clear enough. On balance, in lines 1-3 the riddle seems most likely to be describing the formation of seeds in rose hips, which burst in line four. In this reading, the riddle goes on in the remaining two lines to describe the beautiful flowers of the new plants which (implicitly the next summer) cover their parent rose (line 5), but which are also associated with the rose's defensive thorns (line 6): though the delicate flowers of the rose plant are ostensibly »delicati« ("weak«), its thorns are able to break the plant's stronger assailants (»fortes" - perhaps animals? And perhaps specifically human ones?). Quite why, within the metaphorical world of the poem, sons would cover their mother with a blanket is not obvious to us: Mogford suggests that the poem is evoking real-world sons covering their late mother with a funeral shroud. ${ }^{27}$ If this interpretation is right, it implies that roses change sex from being sons in youth to being mothers as they reproduce, but whatever the precise meaning of the riddle, line two clearly presents the conceit of the self-generating maiden mother.

Two riddles whose solutions are plants exist in the Old Norse riddle corpus, both in the probably thirteenth-century Heiðreks saga, in a riddle contest between the god Óðinn and the protagonist Heiðrekr which accounts for nearly all attested Old Norse riddles. While one of us has previously opined that the riddles were composed especially for the saga, ${ }^{28}$ Burrows has pointed out that the stylistic diversity of its riddles, its demonstrable predilection for integrating pre-existing poems, and the existence of a few other riddles elsewhere in the Old Icelandic corpus make it more likely that the saga drew on pre-existing written riddles a conclusion with which, on reflection, we agree. ${ }^{29}$ One runs as follows: ${ }^{30}$ 
Hverjar eru pær rýgjar á reginfjalli,

elr við kván kona?

Mær við meyju mög um getr,

ok eigut pær varðir vera.

Heiðrekr konungr, hyggðu at gáta!

Who are those ladies on the great mountain;

a woman gives birth by a wife?

A maid by a maiden has a son,

and those wives do not have husbands?

King Heiðrekr, consider solving that!

Heiðrekr - at this point in the story famed for his wisdom - is quick to present the solution: "pat eru hvannir tvær ok hvannarkálfr á milli peira" (»it is two angelicas, and a young angelica in between them "), reflecting the fact that angelicas can in certain conditions reproduce by putting out side shoots. ${ }^{31}$ Christopher Tolkien once asserted that, with only two exceptions, »there are no parallels to " the Heidreks saga riddles "in the riddle-literature of any other country $\aleph^{32}$ - a claim to which more recent commentators have deferred. ${ }^{33}$ But the participation of this riddle in the maiden mother tradition means that we must raise the count of exceptions to three. ${ }^{34}$

Our final early medieval attestation of the maiden mother conceit is closer to Dunash's home and literary sphere, in the form of a poem "fi harshüfa" (»on the artichoke») by the eleventh-century 'Abd Allāh ibn al-Ṭallā' It is recorded in the anthology Rāyāt al-mubarrizin wa-ghàyāt al-mumayyazin by ibn Sa'ìd al-Maghribì (1213-1286), who was widely travelled but most closely associated with al-Andalus: 35

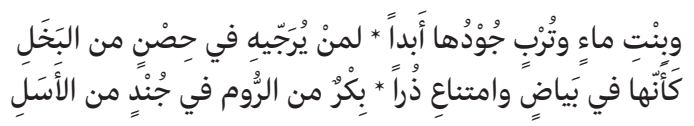

Lo, a daughter of water and earth, her abundance continual * for anyone who aspires to her fortress (also: chastity) of withholding,

as if she, in the whiteness and aloofness of her topmost part, * were a virgin from Byzantium amidst a troop of spears (also: slender twigs/shoots).

It is worth noting that the verb yurajji is masculine: although "anyone " is the most literally correct translation of the subject of this verb, the verb connotes a male challenger to the maiden's fortress. The text of this riddle, like the Bern rose riddle, is not entirely settled: despite working from the same unique manuscript as Dāyah, Gómez's edition reads khidrin (»veil«) where Dāyah's reads jundin (»troop«) (no doubt reflecting the similarity in Arabic script of جند respectively, and perhaps the absence of consonant pointing in the

31 Hervarar saga ok Heiðreks, ed. and trans. Burrows, 430.

32 Saga of King Heidrek the Wise, ed. and trans. Tolkien, xix.

33 Hall, Changing style and changing meaning, 9; Hervarar saga ok Heiðreks, ed. and trans. Burrows, 407.

34 And for a fourth, see Hall, Latin and Hebrew analogues.

35 Ibn Sa'ìd al-Maghribī, Rāyāt al-mubarrizin wa-ghāyāt al-mumayyazìn, ed. Dāyah, 268-269 (with full vocalisation added by us).

36 Ibn Saīì al-Maghribī, Rāyāt al-mubarrizin wa-ghāyāt al-mumayyazìn, ed. Gómez, 110 [verse 305]. 
manuscript).$^{36}$ Gómez's reading inspired A. J. Arberry to render the poem's last four words with the elegant couplet »bashfully she peers | through her veil of spears", but Dāyah's reading is clearly the more direct. ${ }^{37}$ We have not been able to consult the manuscript; what is important for our purposes is that, either way, the white virgin is the edible artichoke heart, which forms as part of the flower at the top of the plant's long stalk. The spears of the final hemistich reflect the scales that cover the bud; here, in a turn characteristic of the last word of Arabic epigrammatic poems,$^{38}$ the poem plays with the meaning of al-asalu, which, within the world conjured up by the poem's metaphors, must have the poetic and somewhat arcane meaning "spears «; but the usual meaning of al-asalu is "slender twigs, shoots", which hints at the vegetal solution to the riddle. ${ }^{39}$ How far the cultivated artichokes of eleventh-century al-Andalus had diverged in form from the wild cardoon of which they are a cultivar is a rather vexed question, ${ }^{40}$ but it is worth noting that cardoon scales can boast a covering of thornlike spines that would fit ibn al-Ṭallä's image of spears admirably.

Ibn al-Tallä does not provide a straightforward attestation of the maiden mother conceit: the artichoke is certainly a chaste virgin, but the text is not explicit that she has daughters. Rather, the maiden/artichoke heart's "jūdu« ("abundance») can be read as the maiden/artichoke heart herself. But the "continual« nature of this abundance can be read to reflect how the artichoke is a perennial, returning year after year, the chaste virgin in a sense the mother of the next year's growth. Alternatively, the riddle can also be read, like some of the others here, as contemplating the artichoke heart as the flower and subsequently seed head that it will become if not harvested. Ibn al-Ṭallä was evidently at least exploring similar ideas to the maiden mother motif in a riddle in the Arabic-speaking Mediterranean of the eleventh century.

"Artichoke« strikes us as the most likely solution to Dunash's riddle as well as ibn al-Tallä's. As a topic for a riddle, it is paralleled elsewhere in the Mediterranean region: of the three true riddles whose solutions are plants in Milovanović's collection of Byzantine riddles, one is on agkinara, which might be translated either as "cardoon " or specifically as "artichoke«. ${ }^{41}$ Milovanović's edition corresponds to the text in the Palatine Anthology: ${ }^{42}$

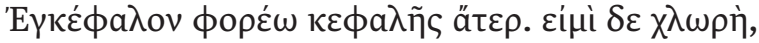

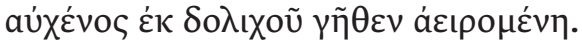

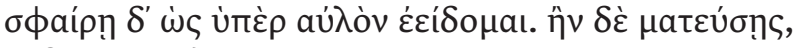

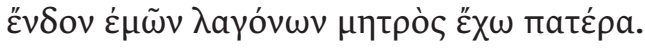

I have a brain without a head, and I am green and rise from the earth by a long neck. I am like a ball placed on a flute, and if you search within my flanks I have there my mother's father.

Byzantina aenigmata, ed. and trans. Milovanović, 19 [no. 6].

Greek Anthology, ed. and trans. Paton, V 54-55. 
Moreover, Milovanović noted that the second half of this text circulated as a riddle in its own right, while consultation of Plutei 32.16 , f. $382 \mathrm{v}$ reveals that the manuscript gives the first couplet alone, showing that it too circulated independently. ${ }^{43}$ Since it is unusual for a riddle to describe the same parts of its subject twice, switching metaphors as it does so, it may be that the four-line riddle in the Palatine Anthology represents the conflation of two two-line riddles on the same subject, which would evidence greater salience again of the cardoon in medieval Greek riddling. Dunash's »they return beautiful, undamaged, * enclosed with fenced gardens « fits the perennial cardoon. Likewise, the enclosure of the virgins by fenced gardens would, within the metaphorical world of Dunash's riddle, denote the enclosure of the artichoke heart by its scales or spines, while playfully making a literal statement about how artichokes grow in gardens.

Meanwhile, there is no longer any need to doubt that the Greek riddle exhibiting the reproducing maiden conceit is, as most commentators have recognised, about a plant. The motif is used of too wide a range of species for us to read it as being particularly well suited to the date palm, but there is no reason to doubt the relatively early manuscript evidence in favour of this solution. The date palm was, after all, an especially popular topic for early medieval plant riddles: it is the solution to the only riddle plausibly attributed in the hadith to the Prophet, ${ }^{44}$ to one of two riddles on plants by the later tenth-century Abū Abdallāh alHusayn ibn Ahmad al-Mughallis, and appears several times in the Latin tradition. ${ }^{45}$

The maiden mother conceit could have travelled between the literary cultures represented by these riddles at least in part in writing. The Greek example is potentially the earliest, but as far as we know, there is no strong evidence for links specifically between the Greek date riddle and the other riddles examined here. Greek influence on epigrammatic Arabic writing seems to be negligible, ${ }^{46}$ but it is not impossible that Greek writing influenced Anglo-Latin riddles. ${ }^{47}$ Symphosius's vine riddle was almost certainly known to the composer of the Bern rose riddle, and Hall has shown elsewhere that a literary link between the Bern Riddles and those of Heidreks saga is possible. ${ }^{48}$ We might also speculate that there were opportunities for the riddles of Symphosius to influence Arabic- and Hebrew-speakers in early medieval al-Andalus; although ibn Sa îd associated ibn al-Tallă with Mahdia, in what is currently Tunisia, sources also associate him with Iberia. The depictions of earth, enclosure and defences in the artichoke riddle by ibn al-Ṭalla' (and to a lesser extent Dunash) recall Symphosius's portrayal of the rose in his riddle $45: 49$

purpura sum terrae, pulchro perfusa rubore, saeptaque, ne violer, telis defendor acutis. o felix, longo si possim vivere fato! 
I am the purple of the earth, steeped in a beautiful blush, and, being hedged around so that I am not attacked, I am defended by sharp weapons. Happy, indeed, if I were able to live a long life.

On the other hand, the conceit could just as well have travelled orally (through international riddle culture of the kind examined by Antti Aarne's Vergleichende Rätselforschungen)..$^{50}$ It is interesting to consider that Symphosius might plausibly have been composing in North Africa, later the home of ibn al-Ṭalla' : both writers might reflect the longue durée of riddle culture in that region. For the most part, then, it is at least as easy to explain the shared conceit of the maiden mother as a product of oral riddle culture as one arising from written transmission.

\section{Plants on Gender}

Though work in critical plant theory spells out convincingly the ecological value of developing plant-centric understandings of the world, that does not mean that we will necessarily find such perspectives in early medieval riddles. Moreover, despite the vegetal solutions to the maiden mother riddles, the metaphors from which those riddles are woven tell us first and foremost about people. It is worth exploring this anthropomorphic dimension both for its intrinsic value as evidence for human culture and en route to ascertaining what, if anything, the riddles can tell us about plants. In particular, the exploration of gender and sexuality is inherent in the maiden mother conceit, as, however light-heartedly, the motif harnesses plants' obvious drive to grow and reproduce along with their ostensible lack of sexual desire and sexual intercourse to the contemplation of women's reproduction and the role of reproduction in gendering. ${ }^{51}$ This initial focus on what the riddles tell us about people will show, however, that from a plant-theory point of view, we can see poetry imagining analogies between plant and human life with great fluency, even in cultures deeply embedded into the Abrahamic positioning of humans on a hierarchy of being apart from animals and even more so from plants, and in cultures which produce profoundly anthropocentric literature.

Notwithstanding the close association between Mary the mother of Jesus and the date palm in Islamic tradition (and the willingness of early medieval Arabic poets to make risque allusions to this association), none of the maiden mother riddles takes up the challenge thrown down by Abū al-Najm Minūchihrī Dāmghānī in Ghaznavid Persia around the 1030s, in a long qașida on wine, to relate the maiden mother conceit to Mary:52

$$
\text { بى شوى شد آبستن جون مريم عمران * وين قصه بسى خوبتر و خوشتر ازانست }
$$

like Mary, 'Imrān's daughter, she's pregnant with no husband, * yet her tale is stranger and sweeter than the tale of Mary.

But the riddles do put the conceit to a great deal of other work.

50 Antti Aarne, Vergleichende Rätselforschungen.

51 Cf. Keetley, Six theses on plant horror, 13-16; Salvador Bello, The sexual riddle type.

52 Minūchihrī Dāmghānī, Dīwān, ed. Kazimirski, s।-v।; trans. Seyed-Gohrab, Courtly Riddles, 49. 
Of the examples of the maiden mother conceit presented above, ibn al-Ṭallä's is the most remarkable for the range of cultural themes it encapsulates: the artichoke is revealed in the riddle not only through environmental conditions, but through familial relations, greed and the guarding of wealth by weapons, skin-colour and perceptions of beauty, and gender and sexual desire. ${ }^{53}$ If the artichoke seemed to ibn al-Tallä an exotic and perhaps high-status vegetable, ${ }^{54}$ that might account for its characterisation as a Byzantine maiden, but the key factor is more likely the stereotypical reputation of Byzantine people in Arabic literature - and especially women - for exhibiting great beauty and, specifically, white complexions, ${ }^{55}$ evoking both the white heart of the artichoke and the pigmentocracy operative in early medieval Arab culture..$^{56} \mathrm{~A}$ racial dimension is not apparent in the other poems..$^{57}$

All of the riddles comment on gender, however, if only as a necessary corollary of using the maiden mother device. El-Cheikh's account of medieval Arab attitudes to the women of Byzantium emphasises how they were imagined not only as beautiful but also as wanton..$^{58}$ None of this comes through in ibn al-Ṭallä's riddle; like the other maiden mother riddles studied here, it focuses on the paradoxical contrast between its subject's fecundity and her chastity. Nevertheless, the power of the beautiful Byzantine virgin to provoke jealous desire is part of how ibn al-Tallä's riddle constructs the desirability of the artichoke: the consumer's breaching of the artichoke's defences is construed as a violation, both of the artichoke herself and of the maiden through whom she is represented. And yet, by invoking men's desire to violate the chastity of beautiful maidens and access their "abundance", the poem implicitly adverts to the possibility that the artichokes would rather be left to thrive in peace; however patriarchal and anthropocentric, the riddle is an acknowledgement, of sorts, of both female and vegetal subjectivity. Dunash's riddle construes its subject in a similar way to ibn al-Tallä's, focusing on associating beauty with chastity and both with enclosure. Dunash's riddle, in noting that (in our reading) the perennial plants will return the next year "kelulot" (»intact «), implicitly contrasts this state with the impending violation of the artichokes that stand before the riddler's eyes in the poem's narrative present. Ultimately, given that the consumption of artichokes must have been seen as a perfectly acceptable undertaking, the riddle serves to normalise this violence.

53 Meghani, Seeing the obscured.

54 Watson, The Arab agricultural revolution, 24-25.

55 El-Cheikh, Byzantium Viewed by the Arabs, 123-124.

56 On which, see Hunwick, A region of the mind; Sharawi, African in Arab culture.

57 It is tempting to seek a racial dimension in the Old Norse angelica riddle. Burrows has read the word rýgjar (»ladies«) in the opening line as meaning not only "ladies« but also "giantesses«: Burrows, Enigma variations, 203204; Burrows, Wit and wisdom, 125; Hervarar saga ok Heiðreks, ed. and trans. Burrows, 429-430. In turn, giants stand as mythological proxies for racial others in Old Norse texts: Cole, In pursuit of an Æsirist ideology. But the only time in Old Norse when this word and its compounds do not straightforwardly denote mundane and culturally Norse women is in one eclectic, inventive, and alliterative list of names and epithets for trollkonur ("witches/ troll-women «): Anonymous Dulur, 'Trollkvenna heitir 5, ed. Gurevich, 730; cf. Sveinbjörn Egilsson, Lexicon poeticum, s.v. rýgr; Dictionary of Old Norse Prose, s.v. rýgr. Accessed on 28 December 2020: onp.ku.dk/onp/onp.php. This is hardly evidence that, as a common noun, rýgr meant "giantess".

58 El-Cheikh, Byzantium Viewed by the Arabs, 123-129. 
The maiden's desire to be spared the attentions of men comes through far more explicitly, however, in Symphosius's riddle - this time with a cheerful sketch of a vivacious and wilful vine, straining against cultivation, surely evoking the licentiousness associated with wine and perhaps evoking Symphosius's integration into, or at least debt to, non-Abrahamic religious culture. Leary has pointed out that the first hemistich (rendered in his translation above as »I do not want to be joined in marriage «) can also be understood to mean »I do not want to be joined [to the vine-support] with a tie-for-binding-vines «, while the last line may refer in its first hemistich (»I do not want to encounter tombs") to a custom of planting grape vines around tombs, and in its second ("I know how to bury myself in the earth ") to a method of training the plant by running a vine along a furrow and burying all but the tip, which then takes root and grows from that new location. ${ }^{59}$ The vine is emphatic that it wants to grow in its own way, in its own place (and away from the dead); the human woman who provides the metaphor for the vine implicitly feels much the same: neither wants to be tied down.

The Old Norse riddle takes this challenge to patriarchal control of women to another level again - perhaps unsurprisingly, since, as we note below, the story troubles patriarchal gender norms at other moments too. Since angelica was important as a food plant and noted for its sweetness, the riddle may be evidence for a mutual association of plant and mother with fertility. ${ }^{60}$ But its representation of gender is more complex than this. All the riddles evoke (only to foreclose) the subversive fantasy of women who are able to reproduce without men, but Óðinn's riddle further challenges heteronormativity by imagining that the reproduction takes place through women's sexual congress. Since representations even of friendships between women are rare in Old Norse literature, this is in its way momentous: ${ }^{61}$ however metaphorical, the riddle is to our knowledge the only representation of female homosexual sex in the corpus. Of course, since the point of the riddle is to set up a paradox which has to be resolved, it is depicting women reproducing with each other precisely to negate the real-world possibility of that, and implicitly the same-sex relationship it depicts is portrayed as no more possible than homosexual reproduction. And yet, as with other riddles in Heidreks saga, the metaphors in this riddle have a literary resonance that suggests that more than this is at stake. It might first be noted that sagas are more forthcoming about intimacy between kinswomen, including women who are kin by marriage, than about non-kin friendship, and in a sense the riddle is consonant with this: ${ }^{22}$ Burrows translated the third line ("elr við kván kona«, translated above as "a woman gives birth by a wife«) as "woman begets with woman «, but while kona is both the usual word for a woman and for a wife, kván certainly means "wife", making it clear that the riddle imagines women who are married, implicitly to one another. ${ }^{63}$ Meanwhile, the challenges that this riddle poses to the gender norms of Abrahamicate cultures fit with how the riddles of Heidreks saga evoke and play with non-Christian Scandinavian mythological traditions. Hannah Burrows has explored Heiðreks saga's evocative series of "wave-riddles", in which the waves of the sea are personified as powerful

59 Symphosius, Aenigmata, ed. and trans. Leary, 157-159.

60 Teixidor-Toneu et al., Sweetness beyond desserts, 296-297.

61 Van Deusen, Sworn sisterhood?

62 Van Deusen, Sworn sisterhood?, 66-67.

63 Hervarar saga ok Heiðreks, ed. and trans. Burrows, 429; Cleasby and Vigfússon, Icelandic-English Dictionary, s.vv. kona, kván; cf. Sveinbjörn Egilsson, Lexicon poeticum, s.vv. kona, kvánfang. 
and dangerous women, and has shown the subtle interplay of this series with non-Christian mythology, positioning them as daughters of the sea god Ægir. This interplay helps the riddles to explore how the waves are, »like Ægir's daughters, both seductive - a source of food and of adventure - and dangerous and unpredictable, taking lives at will «. ${ }^{64}$ The angelica riddle likewise participates in an intense interest in gender transgression in medieval Icelandic writing: ${ }^{65}$ the primeval giant Ymir's asexual reproduction and the transformation of the male god Loki into a sexually active female horse in the early thirteenth-century Snorra Edda; a well-established discourse for expressing one man's power over another through the language of male homosexual sex; ${ }^{66}$ warrior maidens, of whom one of the most renowned is Hervör Angantýsdóttir, the mother of the man to whom the riddle is posed; ${ }^{67}$ and the misogamous maiden-kings of fourteenth- and fifteenth-century Icelandic romance. ${ }^{68}$ Indeed, medieval Icelandic romances, which enjoy fantastic continental settings, are a little more forthcoming on female friendship than sagas set in Iceland, and do sometimes interrupt their fixation on male homosocial relationships for long enough to gesture to homosocial relationships between women, by far the strongest example being the (arguably homoerotic) friendship between the princesses of France and India in the perhaps fourteenth-century Nitída saga.${ }^{69}$ Thus, although the angelica riddle fundamentally negates the homosexuality it portrays, the fact that it represents homosexuality amidst a wide-ranging probing of gender norms in medieval Icelandic writing forbids us from accepting too readily the riddle's implication that women having sex with one another is no more possible than women reproducing with one another. Our surviving evidence affords us only the slightest glimpses into the medieval reception of Heiðreks saga's riddles, ${ }^{70}$ but we can contemplate that, like many erotic riddles, for at least some listeners to the saga, the angelica riddle served to acknowledge taboo realities rather than to deny them. ${ }^{71}$ At the same time, the children of the union between the angelicas are "mög" ("sons") - unlike the clearly female offspring in the Greek fig riddle and the Symphosius and Dunash riddles. The desirability of sons over daughters in Old Norse culture positions this homosexual reproduction as especially fruitful, but in doing so it reinscribes patriarchal gender expectations: it positions sons as the prototypical offspring. Perhaps, just as in Heiðreks saga marriage and childbirth marks the end of Hervör Angantýsdóttir's career as a male viking, the birth of a son returns the queer angelicas to the patriarchal fold. Several ancient and medieval texts from India contemplate reproduction through two women having sex, on the one hand positing this possibility, yet on the other describing how men begotten in such a way are born deformed (specifically through bonelessness)..$^{2}$

64 Burrows, Enigma variations, 213.

65 Cf. Jóhanna Katrín Friðriksdóttir, Women in Old Norse Literature.

66 Meulengracht Sørensen, The Unmanly Man.

67 On whom, see Clover, Warrior maidens and other sons.

68 Kalinke, Bridal-Quest Romance in Medieval Iceland.

69 McDonald Werronen, Popular Romance in Iceland, 171-193; Murath, Invisible kingship.

70 Cf. Hall, Changing style and changing meaning.

71 Cf. Salvador-Bello, Sexual riddle type.

72 Vanita, Born of two vaginas. 
Were similar assumptions or anxieties to have circulated in medieval Iceland, then, arguably, the success of homosexual women in producing sons accentuates the paradoxes at the heart of the angelica riddle, as if sons are an even more surprising product of the union of two women than daughters would have been. On the one hand, the riddle gives the stamp of reproductive success to the angelicas' supposed coupling; on the other, it again circumscribes its own radicalism with patriarchal measures of success.

It is the Bern rose riddle that focuses most intently on offspring, and here too they are masculine (natos), apparently growing up over their mother and enfolding her into heteronormativity - yet implicitly the sons become mothers in turn as they produce their own seeds. Hard though this riddle is to interpret, the sinister image of the sons' birth constituting the wounding of their mother points more than the other riddles analysed here to the alienness of plants, and, however light the tone, the final comment about the rose's thorns defending it emphasises the rose's antagonistic relationship with its environment. ${ }^{73}$

In portraying plants as human maidens and mothers, these riddles explore, in their different ways, women's reluctance to participate in patriarchal sexual relationships (even if the riddles ultimately normalise those relationships). In its simplicity, even the Greek parthénos riddle is heroically insistent on the date palm's self-sufficiency and the irrelevance of male intervention to its production of fruit. The Latin, Arabic, and Hebrew examples develop this theme by positioning the plant as a woman or girl facing unwanted sexual attention, or even predation, from men. On the other hand, the Old Norse angelica riddle both highlights the gender conservatism of most of the plant riddles studied here and the capacity of the peripheral Icelandic culture to cast up subversive perspectives on medieval Abrahamicate norms. All the riddles hint at a patriarchal envy at women's capacity for reproduction, or indeed, in the plants' more alien moments here, fear of it; for all their mentions of chastity, the riddles implicitly recognise that the women have desires, and options.

\section{Critical Plant Studies}

After this long exposition of how riddles write plants as people, it may seem otiose to say that they indicate a readiness to see plants and humans as similar forms of life. Yet recent work in critical plant studies has demonstrated how profoundly Judaeo-Christian theology, Western philosophy, and most ecocriticism have turned away from reading plants as a life form on a continuum with animal, and specifically human, existence. ${ }^{74}$ As Matthew Hall emphasised in his analysis of plants in the Tanakh/Bible, "where plants are ascribed qualities such as perception and sensation, it is clear that these metaphors firmly locate such attributes first and foremost in the human being when they appear «. ${ }^{75}$ This is undeniably also true of the metaphorical logic of the maiden mother riddles: riddles present plants in human terms precisely because plants are recognised not to be human. Where the Bible talks about plants, it tends to focus on plants cultivated for human consumption, ${ }^{76}$ and this anthropocentric focus on cultivated plants likewise extends to most of the maiden mother riddles. Never- 
theless, it is hard to read the portrayals of plants given above without concluding that early medieval commentators perceived and empathised with plants' vivacity. The triple repetition of parthénos ("virgin woman") in the Greek date riddle alone constitutes an insistence on personhood, and the other riddles take this much further. As Dale has emphasised regarding trees in Old English riddles, even an anthropomorphic portrayal of plants is a basis - to some extent a necessary one - for empathy. ${ }^{77}$ Perhaps correspondingly, the riddles for the most part tack away from emphasising the alien dimension of vegetal life - for example, they tend to focus on individual plants rather than a "multiplying mass « of plants, which is liable to evoke horror. ${ }^{78}$ Through this intimate focus on individual plants, the riddles implicitly position plants as being to (human) animals what women are to men: restricted in movement and speech, subject to the gaze or violence of their more vocal and mobile dominators - but having their own subjecthood nonetheless, as well as a capacity for reproduction denied to their oppressor and needed by them. Moreover, since the subjects of most of the maiden mother riddles are food crops, the riddles enable us to contemplate how humans and plants constitute each other through the co-evolutionary interspecies relationships that are agricultural economies, and in turn the way that those economies shape space and constitute place. ${ }^{79}$

Notwithstanding its broad brush-strokes, Matthew Hall's sketch of plants' place across a range of (mostly pre-modern) cultures plausibly identifies a trend in pre-Christian GraecoRoman mythology and in Old Norse accounts of non-Christian Scandinavian mythology whereby plants (admittedly primarily trees) are accorded greater animacy than in JudaeoChristian culture, and our corpus of riddles chimes with this. ${ }^{80}$ Picking up on the Old Icelandic angelica riddle again: it is not known how intensively angelica was managed or cultivated by people in medieval Iceland - or even whether it was first brought there by human settlers or by birds - but it was certainly found on mountainsides in the Middle Ages as in the present day, ${ }^{81}$ and the emphasis of the riddle is firmly on awe at an untamed environment. The riddle opens panoramically, picturing women on a reginfjall. Fjall straightforwardly means "mountain", but the word regin in Old Norse is rich in metaphysical valences: it means "powers", and was also a traditional term for "pagan gods" and even »the world". As the first element of a compound (as here) it generally means "mighty, great " or sometimes "holy"; reginhaf, for example, means "open ocean" (as opposed to the simplex haf, "sea"), while in modern Icelandic reginfjall means "a wild fell, mountain wilderness «.$^{82}$ Correspondingly, the image of the angelica plants as women on a mountainside implies the plants' mobility, wandering beyond the farmstead (as would the human gatherers of angelica itself). And in Heiðrekr's solution to the riddle, the young angelica plant is a hvannarkálfr, literally an "angelica calf«. All this evokes not only a putative heritage of pre-Christian animacy in medieval

\footnotetext{
77 Dale, Natural World in the Exeter Book Riddles, 117-118.

78 Keetley, Six theses on plant horror, 14.

79 Cf. Price, Human and NonHuman, 91-102; Sheshia Galvin, Interspecies relations, 242-244.

80 Hall, Plants as Persons; cf. Bintley, Plant life in the Poetic Edda; Dale, Natural World in the Exeter Book Riddles, 103121; Fay, The farmacy; Abram, Evergreen Ash, 84-102.

81 Teixidor-Toneu et al., Sweetness beyond desserts.

82 Cleasby and Vigfússon, Icelandic-English Dictionary, s.v. Regin; cf. Sveinbjörn Egilsson, Lexicon poeticum, s.v. regin and following.

83 Cf. Abram, Evergreen Ash, 103-107.
} 
Scandinavian culture, but also the riddle's production in a society which was predominantly pastoral rather than agricultural. ${ }^{83}$ Human settlement on Iceland was determined by access to grazing; grazing in turn reshaped the island's ecology; and the angelicas, eking out their survival in this new ecosystem, are read in terms of the animals - human and bovine - with which they contend, gaining a kind of parity with them, and are shown to survive through modes of reproduction alien to their mammalian neighbours.

Meanwhile, Leary's recent edition and translation of Symphosius's riddles expounds thoroughly the degree of viticultural detail which Symphosius wove into his portrayal of the vine as a young woman. ${ }^{84}$ In Symphosius's world, imbued with non-Christian Roman culture, the vine, in her first-person voice, experiences yet strives against intensive training and propagation: though far from the pastoral setting of the angelica riddle, this poem likewise generates a more animate subject than the Abrahamicate Mediterranean texts studied here.

Let us accept the hypothesis that Dunash ben Labraț's maiden mother riddle indeed concerns food plants. If so, the riddles of ibn al-Tallä' and Dunash, in contrast to the riddles of Symphosius and Heiðreks saga, emphasise plants' sessile nature: respectively, the artichoke flower as the virgin at the top of a tower and plants as enclosed maidens. Both riddles, of course, can also be read against the grain: although the enclosure is ostensibly for their protection, the implicit effort to contain these virgins implies that they might be both willing and able to break out of these constraints, for plants are not as sessile as at first glance they might seem, especially in their reproduction. Nevertheless, it is easy to read the Hebrew and Arabic poems as evoking the intensive regime of Mediterranean gardening and cultivation, perhaps specifically in the context of Andrew Watson's celebrated vision of »The Arab agricultural revolution and its diffusion, 700-1100«, in which the artichoke enjoys a significant (if contested) role. ${ }^{85}$ Ibn al-Talla' 's representation of the artichoke as the daughter of water and turbu does not merely present a marriage of water and earth (as our translation above would suggest), but specifically »dust, dry earth «: ${ }^{86}$ while resonating with the elemental and therefore the cosmic, the simplicity of the image of water bringing fertility to dry soil in the context of the poem's tight focus on the individual plant expresses the care and attention paid by the agriculturalist to the plant and its environmental conditions of life.

Dunash, we suggest, presents the artichoke heart surrounded by its scales or spikes as a virgin fenced into a garden, but the fact that artichokes might be fenced into a garden in reality is one of his clues to the reader as to the solution to the riddle. Gardens are fabulously rich sites of symbolic adventure in the Hebrew Andalusi poetry of Dunash and his successors, ${ }^{87}$ and Dunash's maiden mother riddle could be contextualised in relation to this. But here we look instead to a comparison with a different part of his dìwān, a fragmentary verse found in the Cairo Geniza on a letter by Hasdai ibn Shaprut (c. 915-70), thought to be a complaint from Dunash to his master Ḥasdai, following what appears to have been an enforced sepa-

84 Symphosius, Aenigmata, ed. and trans. Leary, 157-159.

85 Cf. Watson, Agricultural Innovation in the Early Islamic World; Wright, Did the Ancients know the artichoke?; Squatriti, Of seeds, seasons, and seas, 1209.

86 Lane, Arabic-English Lexicon, s.v. تُرابُ.

87 E.g. Decter, Iberian Jewish Literature, 79-95. 
ration of Dunash from his wife and son. S. J. Pearce has emphasised the degree to which the poems attributed to Dunash and his wife at the moment of their parting contemplate their mutual affection in economic terms through their exchange of arm-rings - key repositories of moveable wealth in the early medieval world - and the following poem by Dunash continues that theme by referring to commerce in agricultural produce. ${ }^{88}$ The first two lines are illegible; the remainder read: 89

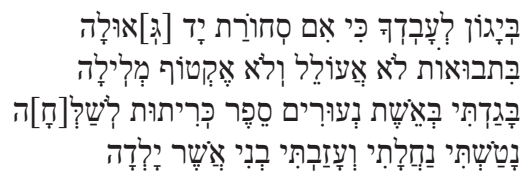

I served you in sorrow, for all your wares are loathsome.

I will glean no grapes, nor will I gather corn.

I betrayed a young wife and sent her a writ of divorce.

I left my home, and abandoned the son that she bore.

The composition of this complaint could have been widely separated in time from the composition of Dunash's maiden mother riddle; there is nothing to say which was composed first; and there is no demand to read Dunash's riddle as addressing an actual son. Yet the comparison with the riddle is striking. The riddle is the only one of the ten in Halper 317 to specify the addressee as bni ("my son"). The relationship between the implicit speaker and his son stands in contrast with the maidens who are the subject of the riddle, the men's gaze ranging over the enclosed women, their words defining them as they contemplate chaste women who nonetheless "return, undamaged «, in what we have read as literal agricultural fecundity and metaphorical human women's reproductive self-sufficiency. By contrast, in the poem to Hasdai, Dunash positions himself as severed from his son, while still contemplating a young single mother, and rather than associating the woman with fruitfulness, the estranged husband conversely associates his abandonment of his wife and son with either a refusal or inability on his part to reap a harvest. The conceptual structure here is along the same lines as the injunction of Qur'àn 2:223: "nisā ukum harthun lakum fatū harthakum annā shi' tum waqaddimū li-anfusikum« ("your wives are [like] your fields, so go into your fields whichever way you like, and send [something good] ahead for yourselves «)..$^{90}$ There are several hierarchical relationships implied in Dunah's poem: Hasdai has some kind of mastery over Dunash; Dunash has (or had) a patriarchal superiority over his wife and son; and the men in the poem also view themselves as standing above grapes and corn in the order of things. Reading Dunash's complaint alongside the riddle, we can glimpse men blurring admiration for women's capacity to reproduce with enthusiasm for reaping agricultural bounty, and a man lamenting his severing from his progeny by describing his

88 Pearce, Bracelets are for hard times.

89 Fleischer, le-toldot shirat ha-hol ha-ivrit bi-sefarad bi-reshitah, 218; trans. Hoffman and Cole, Sacred Trash, 181.

90 Qur'ān, ed. Quranic Arabic Corpus; trans. Abdel Haleem. 
alienation from the harvest whose commodification has demanded their separation. When agriculture ceases to be primarily about sustaining the material needs of Dunash's family and their proximity in space, the metaphorical bond between the human and the cultivated plant breaks. In these ways, Dunash positions his superiority over his wife and child as metaphorically equivalent to superiority over crops - but he turns away from presenting his own state of oppression in the same terms, presenting himself as a frustrated harvester rather than in any sense a harvest. The intersection of Dunash's recognition of the suffering of his wife and son and, in the riddle, his reading of plants as maidens whose harvest is, implicitly, a violation, implies a recognition of plants' suffering - but in both cases, Dunash reads that relationship through a patrician lens of superiority and responsibility.

\section{Conclusions}

This study, the first extensive examination of riddles whose solutions are plants, has established some useful facts in the study of early medieval riddles - a genre which, beyond Old English and Latin, has enjoyed scant attention. Across Latin, Arabic, Greek, Old Norse and, we argue, Hebrew riddles on plants, we can see the circulation of a conceit whereby the plant is construed as a maiden who is paradoxically a mother. By extending the scope of our primary sources beyond Latin and English - the hegemonic languages of the Western academy - to range across the early medieval riddle corpus, we have shown that there is no need to doubt the manuscript solution to the Greek date riddle; that a plausible solution is available for one of Dunash ben Labraț's that has hitherto perplexed scholars; and that the Old Norse riddles of Heiðreks saga are not as isolated from wider Eurasian riddling traditions as has been supposed. We have also drawn attention to the angelica riddle as possibly the only portrayal of female same-sex coupling in the Old Norse corpus.

One of the various Arabic terms for siddle is mu'ammā, which literally means »obscured, blinded «, a term which engages us with the problem of perception: not being able to see what is nevertheless there, or seeing only what gives the obscured object shape. Crucially, it invites us to reveal the unseen. The relevance of the riddles we have studied here to ameliorating what Wandersee and Schussler labelled "plant blindness" will be obvious. ${ }^{91}$ While critical plant theory has focused - justifiably - on enabling human understanding of the Earth's current ecological crisis, these plant riddles also remind us of the extensive diffusions in Western Eurasian history and pre-history of cultivable plants and agricultural technologies, and likewise the degree to which linguistically, culturally, and geographically disparate people nonetheless participated in shared literary cultures and shared methods for exploring human culture by contemplating the plants with which they co-existed.

The riddles studied here are on the whole far shorter than most of their Old English counterparts, making it harder to see in them the sprawling, rhizomatic assemblages that ecocritically minded scholars have come to celebrate in Old English riddles. Their neglect thus recalls Adam Talib's argument that scholars steeped in Western poetic traditions have struggled to come to grips with the short poems of the epigrammatic traditions found in Arabic and beyond..$^{92}$ Yet we have shown how dense and evocative these short riddles can be,

91 Wandersee and Schussler, Preventing plant blindness.

92 Talib, How Do You Say ,Epigram in Arabic?, esp. 183-212. 
and how concertedly they explore human relations - particularly gender and its relationship with movement and reproduction. And we have been able to show that these riddles are not merely anthropocentric. The sample of literature determined for us by a particular motif provides a small but independent correlation for Matthew Hall's survey of the ideological position of plants in pre-modern cultures (and has extended his focus from Christianity some distance into wider Abrahamicate culture). By drawing on his and other recent work in critical plant theory, we have been able to find implicit recognitions in several of these riddles of the dynamic and reciprocal relationships between human farmers and their family structures, the plants that domesticate them, their mutual shaping of the ecosystems they inhabit or colonise, and the economies that these interactions constitute.

The dominant tone in the riddles is perhaps the patrician one that we have identified in Dunash ben Labraț's work, whereby men see themselves as above both women and plants, reading the two subjected groups as metaphorically equivalent, gazing upon them and gathering their offspring to themselves, and understanding themselves as bearing a responsibility towards them. Yet these riddlers cannot avoid recognising the restrictions that this hierarchy places on the oppressed, and the desire of plants and women to flourish and grow (and reproduce) without constraint or violence. And as we probe the edges of the Abrahamicate world - Symphosius, writing relatively early in the conversion of the Mediterranean to Abrahamic religions, Heiðreks saga, geographically at the periphery of the medieval Abrahamicate world - we see a less patrician tone, the plants livelier, queering gender from their own distinctive ecologies.

\section{Acknowledgements}

For assistance and guidance on various points, we are particularly indebted to Yaara Naor Elman, Maroula Perisanidi, Saadia Gamir, Irina Dumitrescu, Eva Frojmovic, Tuija Ainonen, Francesca Petrizzo, Matthew Keegan and Neville Mogford. 


\section{References}

\section{Manuscripts}

Halper 317 = Philadelphia, University of Pennsylvania, Center for Advanced Judaic Studies Library, Cairo Genizah Collection, Halper 317; open-access facsimile: openn.library. upenn.edu/Data/0002/html/h317.html.

Plutei 32.16 = Florence, Biblioteca Medicea Laurenziana, Plutei 32.16; open-access facsimile: mss.bmlonline.it/s.aspx?Id=AWOIfIkII1A4r7GxMILA\#/book.

Aarne, Antti, Vergleichende Rätselforschungen, Folklore Fellows Communications 26-28, 3 vols. (Helsinki, 1918-1920).

Abram, Christopher, Evergreen Ash: Ecology and Catastrophe in Old Norse Myth and Literature (Charlottesville, 2019).

al-Tha'ālibī, Abū Manșūr, Tatimmat al-Yatìmah, ed. Ahmad Shawqi Radwan, Tha'ālibì's 'Tatimmat al-Yatimah: A Critical Edition and a Study of the Author as Anthologist and Literary Critic. Unpublished $\mathrm{PhD}$ thesis (University of Manchester, 1972).

Aenigmata in Dei nomine Tullii seu aenigmata quaestionum artis rhetoricae [aenigmata sbernensiar], ed. François Glorie, trans. Karl J. Minst, in: Tatuini omnia opera, Variae collectiones aenigmatum merovingicae aetatis, Anonymus de dubiis nominibus, François Glorie (ed.), Corpus christianorum: series latina 133-133a, 2 (Turnholt, 1968) 541-610.

Allor, Danielle and Haylie Swenson, Writing with plants, Postmedieval: A Journal of Medieval Cultural Studies 9 (2018) 496-510.

Anonymous Pulur, 'Trollkvenna heiti 5, ed. Elena Gurevich, in: Kari Ellen Gade and Edith Marold (eds.), Poetry from Treatises on Poetics, Skaldic Poetry of the Scandinavian Middle Ages 3 (Turnhout, 2017).

Anthologie Grecque: Première Partie Anthologie Palatine, Tome XII (Livres XIII-XV), ed. and trans. Félix Buffière (Paris, 1970).

Bintley, Michael D. J., Plant life in the Poetic Edda, in: Simon C. Thomson and Michael D. J. Bintley (eds.), Sensory Perception in the Medieval West, Utrecht Studies in Medieval Literacy 34 (Turnhout, 2016) 227-244.

Bitterli, Dieter, Say What I am Called: The Old English Riddles of the Exeter Book and the AngloLatin Riddle Tradition, Toronto Anglo-Saxon Series 2 (Toronto, 2009).

Burrows, Hannah, Enigma variations: wave-riddles and supernatural women in Old Norse poetic tradition, Journal of English and Germanic Philology 112 (2013) 194-216.

Burrows, Hannah, Wit and wisdom: the worldview of the Old Norse-Icelandic riddles and their relationship to Eddic poetry, in: Martin Chase (ed.), Eddic, Skaldic, and Beyond: Poetic Variety in Medieval Iceland and Norway (New York, 2014) 114-135.

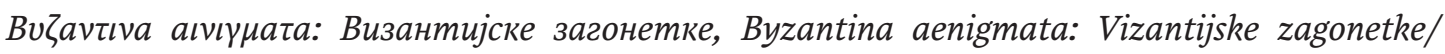

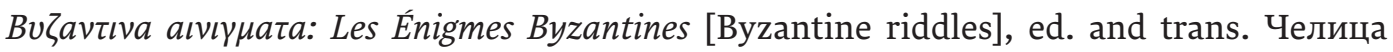
Миловановић/Čelica Milovanović, Српска академија наука и уметности, Одељење језика и књижевности, Балканске народне умотворине [Odeljenje jezika i knjizevnosti. Balkanske narodne umotvorine]/Académie Serbe des Sciences et des Arts, Classe de langage et de littérature, Littérature orale des Balkans 6 (Belgrade, 1986).

Cleasby, Richard and Gudbrand Vigfusson, An Icelandic-English Dictionary (2nd edition by William A. Craigie) (Oxford, 1957).

Clover, Carol J., Warrior maidens and other sons, Journal of English and Germanic Philology 85 (1986) 35-49. 
Cole, Richard, In pursuit of an Æsirist ideology, Viking and Medieval Scandinavia 15 (2019) 65-101.

Dale, Corinne, The Natural World in the Exeter Book Riddles (Woodbridge, 2017).

Decter, Jonathan P., Iberian Jewish Literature: Between al-Andalus and Christian Europe (Bloomington, 2007).

Delgado, José Martínez, Dunash ben Labraț ha-Levi, in: Norman A. Stillman et al. (eds.), Encyclopedia of Jews in the Islamic World (Leiden, 2010).

Diccionario griego-español (Madrid, 1989-).

Dictionary of Old Norse Prose (Copenhagen, 1983-).

Dunash ben Labraț ha-Levi, דיוואן, diwan [diwan], trans. Carlos del Valle Rodríguez, El diván poético de Dunash ben Labrat: la introducción de la métrica árabe (Madrid, 1988).

Dunash ben Labrat ha-Levi, חידות, hidot [riddles], ed. Nehemya Aluny, Ten Dunash ben Labrat's riddles, The Jewish Quarterly Review, New Series 36 (1945) 141-146.

El-Cheikh, Nadia Maria, Byzantium Viewed by the Arabs, Harvard Middle Eastern Monographs 36 (Cambridge, MA, 2004).

Fay, Jacqueline, The farmacy: wild and cultivated plants in early medieval England, ISLE: Interdisciplinary Studies in Literature and Environment ([no date]), DOI: 10.1093/isle/ iszo85.

Fleischer, Ezra, לתולדות שירת החול העברית בספרד בראשיתה, le-toldot shirat ha-ḥol ha-ivrit bi-sefarad bi-reshitah [on the emergence of Hebrew secular poetry in Spain], in: Menahem BenSasson, Robert Bonfil and Joseph R. Hacker (eds.), Culture and Society in Medieval Jewry: Studies Dedicated to the Memory of Haim Hillel Ben-Sasson Jubilee Volume (Jerusalem, 1989) 197-225.

The Greek Anthology, ed. and trans. William R. Paton, Loeb Classical Library 67-68, 84-86 (Cambridge, MA, 1916-1918).

Hall, Alaric, Changing style and changing meaning: Icelandic historiography and the medieval redactions of Heidreks saga, Scandinavian Studies 77 (2005) 1-30.

Hall, Alaric, Latin and Hebrew analogues to the Old Norse leek riddle, Medieval Worlds 14 (2021) 289-296.

Hall, Matthew, Plants as Persons: A Philosophical Botany (Albany, 2011).

Hervarar saga ok Heiðreks, ed. and trans. Hannah Burrows, in: Margaret Clunies Ross (ed.), Poetry in >Fornaldarsögur: Part 1, Skaldic Poetry of the Scandinavian Middle Ages 8 (Turnhout, 2017) 367-487.

Hodgson, Marshall G. S., The Venture of Islam: Conscience and History in a World Civilization, 3 vols. (Chicago, 1974).

Hoffman, Adina and Peter Cole, Sacred Trash: The Lost and Found World of the Cairo Geniza (New York, 2011).

Hunwick, John O., A region of the mind: medieval Arab views of African geography and ethnography and their legacy, Sudanic Africa 16 (2005) 103-136.

Ibn Gabirol, Shelomo ben Yehudah, שירי שלמה בן יהודה אבן גבירול :מקובצים על פי ספרים וכתבייד, Shire Shelomoh ben Yehudah ibn Gabirol: mekubatsim ' al-pi sefarim ye-kitve-yad [poems of Shelomoh ben Yehudah ibn Gabirol: compiled from books and manuscripts], ed. Hayyim Nahman Bialik and Yehoshua Ḥana Rawnitzki, 7 vols (Tel 'Aviv, 1927-1932). 
Ibn Sa'ìd al-Maghribī, Abū al-Ḥasan 'Alī ibn Mūsā, رايات المبرزين وغايات المميزين, rāyāt almubarrizin wa-ghāyāt al-mumayyazin [banners of the champions and pennants of the distinguished], ed. Emilio García Gómez, El libro de las banderas de los campeones, de Ibn Sa íd al-Magribi (Madrid, 1942); also ed. محمد رضوان الداية [Muhammad Riḍān Dāyah], Damascus, 1987; trans. A. J. Arberry, Moorish Poetry: A Translation of >The Pennants', an Anthology Compiled in 1243 by the Andalusian Ibn Sa'id (Cambridge, 1953).

Jóhanna Katrín Friðriksdóttir, Women in Old Norse Literature: Bodies, Words, and Power (New York, 2013).

Kalinke, Marianne E., Bridal-Quest Romance in Medieval Iceland, Islandica 46 (Ithaca, NY, 1990).

Keegan, Matthew L., Levity makes the law: Islamic legal riddles, Islamic Law and Society 27 (2020) 214-239.

Keetley, Dawn, Introduction: six theses on plant horror; or, why are plants horrifying?, in: Dawn Keetley and Angela Tenga (eds.), Plant Horror: Approaches to the Monstrous Vegetal in Fiction and Film (London, 2016) 1-30.

Klein, Thomas, Pater occultus: the Latin Bern Riddles and their place in early medieval riddling, Neophilologus 103 (2019) 399-417.

Lane, Edward William, An Arabic-English Lexicon, vols. 6-8, ed. Stanley Lane-Poole, 8 vols. (London, 1863-1893).

McDonald Werronen, Sheryl, Popular Romance in Iceland: The Women, Worldviews, and Manuscript Witnesses of >Nitída sagar, Crossing Boundaries: Turku Medieval and Early Modern Studies 5 (Amsterdam, 2016).

Meghani, Shamira A., Seeing the obscured, in: John Howard (ed.), White Sepulchres: Palomares Disaster Semicentennial Publication, Biblioteca Javier Coy d'estudis nordamericans 128 (Valencia, 2016) 121-126.

Meulengracht Sørensen, Preben, The Unmanly Man: Concepts of Sexual Defamation in Early Northern Society, trans. by Joan Turville-Petre from Norrønt nid: forestillingen om den umandige mand $i$ de islandske sagaer (Odense, 1980), The Viking Collection: Studies in Northern Civilization 1 (Odense, 1983).

Milovanović-Barham, Čelica, Aldhelm's Enigmata and Byzantine riddles, Anglo-Saxon England 22 (1993) 51-64.

Minūchihrī Dāmghānī, Abu 'l-Najm Aḥmad ibn Qawṣ ibn Aḥmad, Dīwān, ed. A. de Biberstein Kazimirski, Manoutchehri: Poète persan du 11ème siècle de notre ère (du 5ième de l'hégire): Texte, traduction, notes, et introduction historique (Paris, 1886).

Mogford, Neville, The moon and stars in the Bern and Eusebius riddles, in: Megan Cavell and Jennifer Neville (eds.), Riddles at Work in the Early Medieval Tradition: Words, Ideas, Interactions (Manchester, 2020) 230-246.

Mogford, Neville, Commentary on Bern Riddle 52, in Megan Cavell et al. (eds), The Riddle Ages: Early Medieval Riddles, Translations and Commentaries. Accessed on 31 March 2021: theriddleages.bham.ac.uk/riddles/post/commentary-on-bern-riddle-52-de-rosa/.

Murath, Antonia, Invisible kingship: liminality and the maiden king in Nitíða saga, European Journal of Scandinavian Studies, 50/2 (2020), DOI: 10.1515/ejss-2020-2002.

Murphy, Patrick J., Unriddling the Exeter Riddles (University Park, PA, 2011).

Nealon, Jeffrey T., Plant Theory: Biopower and Vegetable Life (Stanford, 2015).

Niles, John D., Old English Enigmatic Poems and the Play of the Texts, Studies in the Early Middle Ages 13 (Turnhout, 2006).

Ohlert, Konrad, Rätsel und Rätselspiele der alten Griechen (Berlin, 1886). 
Paz, James, Nonhuman Voices in Anglo-Saxon Literature and Material Culture (Manchester, 2017).

Pearce, S. J., Bracelets are for hard times: economic hardship, sentimentality and the Andalusi Hebrew poetess, Cultural History 3 (2014) 148-169.

Price, Helen, Human and NonHuman in Anglo-Saxon and British Postwar Poetry: Reshaping Literary Ecology. Unpublished PhD thesis (University of Leeds, 2013).

Qurān, ed. Quranic Arabic Corpus, version 0.4 (University of Leeds, 2011); trans. M. A. S. Abdel Haleem, The Qur'ān (Oxford, 2004).

Robinson, Francis, Global history from an Islamic angle, in: James Belich, John Darwin, Margret Frenz and Chris Wickham (eds.), The Prospect of Global History (Oxford, 2016) 127-145.

The Saga of King Heidrek the Wise, ed. and trans. Christopher Tolkien (London, 1960).

Said, Edward W., Culture and Imperialism (New York, 1994).

Salvador-Bello, Mercedes, The sexual riddle type in Aldhelm's Enigmata, the Exeter Book, and early medieval Latin, Philological Quarterly 90 (2012) 357-385.

Sebo, Erin, In Enigmate: The History of a Riddle, 400-150o (Dublin, 2018).

Sebo, Erin, Was Symphosius an African? A contextualizing note on two textual clues in the Aenigmata Symphosii, Notes and Queries 56 (2009) 324-326.

Seyed-Gohrab, Ali Asghar, Courtly Riddles: Enigmatic Embellishments in Early Persian Poetry (Leiden, 2010).

Sharawi, Helmi, The African in Arab culture: dynamics of inclusion and exclusion, in: Tahar Labib (ed.), Imagining the Arab Other: How Arabs and Non-Arabs View Each Other (New York, 2008).

Sheshia Galvin, Shaila, Interspecies relations and agrarian worlds, Annual Review of Anthropology 47 (2018) 233-249.

Squatriti, Paolo, Of seeds, seasons, and seas: Andrew Watson's medieval agrarian revolution forty years later, The Journal of Economic History 74 (2014) 1205-1220.

Sveinbjörn Egilsson, Lexicon poeticum antiquæ linguæ septentrionalis/Ordbog over det norskislandske skjaldesprog (2nd edition by Finnur Jónsson) (Copenhagen, 1931).

Symphosius, Aenigmata, ed. Timothy J. Leary, The Aenigmata: An Introduction, Text and Commentary (London, 2014).

Talib, Adam, How Do You Say 'Epigram < in Arabic? Literary History at the Limits of Comparison, Brill Studies in Middle Eastern Literatures 40 (Leiden, 2018).

Teixidor-Toneu, Irene, Karoline Kjesrud, Anneleen Kool, Sweetness beyond desserts: the cultural, symbolic, and botanical history of angelica (Angelica archangelica) in the Nordic region, Journal of Ethnobiology 40 (2020) 289-304.

Van Deusen, Natalie M., Sworn sisterhood? On the (near-) absence of female friendship from the Íslendingasegur, Scandinavian Studies 86 (2014) 52-71.

Vanita, Ruth, Born of two vaginas: love and reproduction between co-wives in some medieval Indian texts, GLQ: A Journal of Lesbian and Gay Studies 11 (2005) 547-577.

Wandersee, James H. and Elisabeth E. Schussler, Preventing plant blindness, The American Biology Teacher 61 (1999) 82-86.

Watson, Andrew M., The Arab agricultural revolution and its diffusion, 700-1100, The Journal of Economic History 34 (1974) 8-35.

Watson, Andrew, Agricultural Innovation in the Early Islamic World: The Diffusion of Crops and Farming Techniques 700-1100 (Cambridge, 2008). 
Weingarten, Susan, The rabbi and the emperors: artichokes and cucumbers as symbols of status in talmudic literature, in: David M. Schaps, Uri Yiftach and Daniela Dueck (eds.), When West Met East: The Encounter of Greece and Rome with the Jews, Egyptians, and Others. Studies Presented to Ranon Katzoff in Honor of his 75th Birthday, Storia e civiltà, 3 (Trieste, 2016) 51-65.

Wright, Clifford A., Did the Ancients know the artichoke?, Gastronomica: The Journal of Food and Culture 9/4 (2009) 21-28. 